\title{
MOMENTO INTEGRAL
}

\begin{abstract}
En este momento
hay algo de extraño en mi cuarto.

Hay dos ojos verdes flotando en la vaguedad,

hay mil ángeles intentando romper las persianas cerradas,

hay un gran silencio y una gran soledad.

Hay estremecimientos de carne insatisfecha,

hay dibujos disformes que se están moviendo.

hay el espíritu de Dios (tal vez sea el espiritu de Dios)

detrás de los estantes, velando mis pensamientos más secretos, y hay el suicidio escondido en el cajón, entre poemas olvidados, el suicidio que sorprendió a aquel primo mio, muy alto y flaco.
\end{abstract}

\section{CAMINOS}

Me sumergiré en los mares

y traeré de las profundidades de las aguas verdes náufragos en desesperación

y líquenes y sargazos

pegados a mis piernas

y colgando como hilos de mis cabellos.

Mis ojos tendrán la sensación virgen

de admirar tierras desconocidas.

Descortezaré mis pies en las escarpas de las montañas.

Dejaré en todo un estigma de mi pasaje.

Dejaré en las espinas de los cardos

harapos de mi propia carne.

Enrique Larreta, Santa María del Buen Aire. Tiempos iluminados.Buenos Aires, Espasa-Calpe Argentina, S. A. (Colección Austral), 1941. 176 pp.

Si bien Larreta es ampliamente conocido en todos los países hispanoparlantes, corresponde destacar que en algunos esa divulgación se refiere únicamente a su gran novela La gloria de don Ramiro y quizá, un poco, a Zogoibi. Conviene señalar que este artista argentino ha continuado su obra, buscando siempre nuevas facetas, cuyo conjunto forma un todo armónico. La gloria de don Ramiro, universalmente conocida, tiene, sobre las nuevas obras de Larreta, la ventaja de ser la hermana mayor, la que más ha viajado. Junto a ella, coloquemos las nuevas obras de este admi- 
rable escritor, y sobre todo El linyera y Santa Maria del Buen Aire, en que podemos valorar al dramaturgo de alta jerarquía. El linyera fué llevada al cine. Santa María del Buen Aire obtuvo, en los teatros platenses, rotundo éxito. Sin embargo, esta última obra -perfectamente representable, por sus virtudes de auténtico teatro- es más propicia para la lectura, y sobre todo, para la relectura. Es la reconstrucción histórica, realizada con erudición y con amplio sentido artístico. Pedro de Mendoza, el fundador de la hoy opulentísima ciudad de Buenos Aires, necesitaba una obra como ésta, pues su vida posee pasajes más que suficientes para una realización de vivo interés. Al dramatizar los más salientes rasgos de su epopeya, Larreta ha demostrado una vez más su poder de creador y de re-creador, dando nueva vida - vida estética- a lo que parecería únicamente destinado a vegetar en la frialdad histórica. El mismo define el carácter de su obra: "Coger una de esas hojas desecadas que una soñadora costumbre solía esconder en otros tiempos, entre las páginas de un libro, devolverle su color, su parénquima, pintarla de sol, de luna, de tempestad, y hacerla temblar en el aire de la vida, sin quebrar sus nervios, sin descomponer su forma, de modo que el botánico pudiera luego identificarla, he ahí metafóricamente lo que me propuse con esta reconstrucción". Y los tres actos -agreguemos- realizan noblemente ese ideal, en su perfecta arquitectura teatral, en su vivo dialogado, su interés creciente.

Tiempos iluminados, que acompaña a este drama, es una deliciosa serie de recuerdos de viaje y de arte, del propio autor, en su vida en Europa $y$ en la Argentina. Escritas en prosa muy depurada, estas memorias presentan magníficos sonetos de Larreta, que es poeta inspiradisimo.

Este tomo, finamente impreso, contribuirá a una mayor fraternidad, en los países hispanoparlantes, con dos obras interesantísimas del gran escritor argentino.

Selva Márquez, el gallo que gira.-Montevideo, "La Industrial Gráfica Uruguaya", 1941. 66 pp.

La poesía de esta joven uruguaya está llamada a tener muy pronto vasta repercusión en los países hispanoparlantes. Si hasta ahora Selva Márquez es poco conocida fuera de los países del Plata, ello se debe a la propia autora, que por exceso de modestia o por falta de tiempo - sus días son laboriosísimos- no se preocupa de difundir su obra en los demás países de América.

Ha publicado, hasta ahora, tres libros: Viejo reloj de cuco (1935); Dos (1936) y este Gallo que gira, donde su lirismo ha llegado a una gran depuración, a una intensidad emotiva vivísima. 